\title{
PERANCANGAN APLIKASI LOWONGAN KERJA BERBASIS WEB
}

\author{
Diki Anggana Cipta Wahyu Nur Alam ${ }^{1}$, Linda Salma Angreani ${ }^{2}$ \\ ${ }^{1}$ LAPAN Indonesia, Email: dikianggana@gmail.com \\ ${ }^{2}$ Teknik Informatika UIN Maulana Malik Ibrahim Malang, Email : linda@uin-malang.ac.id
}

\begin{abstract}
Abstrak-Website lowongan kerja merupakan salah satu website yang paling banyak diakses oleh masyarakat Indonesia. Hal ini disebabkan semakin meningkatnya jumlah pencari kerja di Indonesia yang mencari pekerjaan. Akan tetapi, sebagian besar website lowongan kerja yang ada umumnya menetapkan tarif yang terbilang mahal bagi perusahaan yang ingin memasang iklan lowongan kerja. Selain itu, mayoritas website lowongan kerja hanya menyediakan informasi lowongan kerja dan fasilitas melamar kerja secara online saja. Fasilitas yang disediakan bagi perusahaan dan pencari kerja dalam website tersebut sangat terbatas. Para pengguna website lowongan kerja tidak memiliki media yang efektif untuk dapat berinteraksi dan membangun komunikasi yang baik satu sama lain. Oleh karena itu, para pengguna website lowongan kerja cenderung menjadi pengguna pasif.

Aplikasi lowongan kerja berbasis web dibangun menggunakan HTML (Hypertext Markup Language) sebagai bahasa penandaan dokumen teks, PHP (Hypertext Preprocessor) sebagai script dan objek yang dikembangkan untuk memperluas kemampuan HTML, dan MySQL sebagai database pendukungnya.

Berdasarkan pengujian, aplikasi yang dibangun dapat meningkatkan fungsi sebuah website lowongan kerja secara keseluruhan sehingga para pengguna website menjadi aktif dalam menggunakan fasilitas yang tersedia secara cuma-cuma.
\end{abstract}

Kata Kunci: Web, Lowongan kerja.

\section{PENDAHULUAN}

Teknologi yang berkembang dengan pesat menjadi salah satu penyokong kehidupan manusia. Apalagi dalam pemenuhan kebutuhan informasi, manusia seringkali menggunakan teknologi, seperti internet. Internet bahkan menjadi satu kebutuhan pokok yang tidak dapat ditinggalkan.

Setiap orang dapat mencari dan menyediakan informasi dengan mudah melalui internet. Internet menjadi suatu fenomena menarik yang banyak mendatangkan manfaat bagi kehidupan manusia. Banyak kemudahan yang disediakan oleh internet, seperti World Wide Web (WWW) atau sering juga disebut dengan website. Internet sebagai penyedia informasi banyak diaplikasikan untuk membuat beragam jenis website, salah satunya adalah website lowongan kerja. Di Indonesia, terdapat banyak website yangmenyajikan informasi lowongan kerja.

Akan tetapi, mayoritas website tersebut umumnya hanya menyediakan fasilitas input lowongan kerja bagi perusahaan dan fasilitas melamar kerja online bagi para pencari kerja atau pelamar. Aktivitas yang dapat dilakukan keduanya dalam menggunakan website cenderung terbatas. Terlebih lagi banyak website yang menetapkan tarif bagi perusahaan yang ingin memasang iklan lowongan kerja, seperti misalnya jobsdb.com, datakarir.com, jobstreet.com, jobindo.com, ggkarir.com dan lain-lain.

Perusahaan dan pelamar membutuhkan sebuah media yang menuntut peran aktif kedua belah pihak guna membangun komunikasi dan kerja sama yang baik. Perusahaan yang memasang iklan lowongan kerja sering kali mengalami kesulitan untuk mendapatkan pelamar yang sesuai dengan kriteria yang diinginkan. Sedangkan para pelamar cenderung mengalami kesulitan untuk berekspresi atau menuangkan pikirannya dalam website karena akses yang disediakan sangatlah terbatas. Oleh karena itu, dibutuhkan inovasi website lowongan kerja gratis yang menyediakan fasilitasfasilitas unik sehingga para pengguna website lebih aktif dalam memanfaatkan website tersebut secara cuma-cuma.

Maksud dari penelitian dan pembuatan aplikasi ini adalah untuk membangun aplikasi website lowongan kerja yang dilengkapi fasilitas inovatif dan berbeda dengan website-website lowongan kerja pada umumnya.Adapun tujuan yang akan 
dicapai dari penulisan skripsi ini adalah sebagai berikut:

1. Memberikan fasilitas pencarian lowongan yang lebih menarik dan lebih cepat.

2. Memberikan fasilitas yang mempermudah perusahaan untuk menentukan pelamar yang cocok dengan lowongan pekerjaan yang ada.

3. Memberikan fasilitas pada pelamar agar pelamar dapat melamar dengan cepat dan efisien.

4. Memberikan fasilitas pada perusahaan dapat meng-invite atau mengundang pelamar dengan cepat.

\section{MODEL, ANALISA, DESAIN,} DAN IMPLEMENTASI

\section{A. MODEL}

Teknik analisis data dalam pembuatan perangkat lunak menggunakanmodel pengembangan perangkat lunak Waterfall, penjelasannya yaitu sebagai berikut :

\section{a. Rekayasa Sistem}

Tahap ini merupakan kegiatan pengumpulan data sebagai pendukung pembangunan system, menentukan ke arah mana aplikasi ini akan dibangun.

b. Analisis Sistem

Merupakan tahap menganalisis hal-hal yang diperlukan dalam pelaksanaan proyek pembuatan perangkat lunak.

c. Perancangan Sistem

Proses ini digunakan untuk mengubah kebutuhan-kebutuhan diatas menjadi representasi ke dalam bentuk rancangan software sebelum codingdimulai. Design harus dapat mengimplementasikan kebutuhan yang telah disebutkan pada tahapan analisis sebelumnya.

\section{d. Pengkodean Sistem}

Untuk dapat dimengerti oleh mesin, dalam hal ini adalah komputer, maka desain tersebut harus diubah bentuknya menjadi bentuk yang dapat dimengerti oleh mesin, yaitu ke dalam bahasa pemrograman melalui proses coding.

\section{e. Pengujian Sistem}

Penyatuan unit-unit program kemudian diuji secara keseluruhan, pengujian dilakukan untuk mengetahui kelebihan dan kekurangan sistem.

\section{f. Pemeliharaan Sistem}

Setelah aplikasi ini diimplementasikan pada lingkungan distro Fathinside, maka diperlukan pemeliharaan aplikasi untuk mengecek apakah masih ada kesalahan sistemyang tidak ditemukan sebelumnya.

\section{g. Umpan Balik}

Merupakan respon dari pengguna sistem yang bisa digunakan untuk mengetahui sejauh mana aplikasi yang dibangun diterima penggunanya.

\section{B. ANALISIS}

Analisis Prosedur yang sedang berjalan

Berdasarkan hasil penelitian, terdapat aplikasi lowongan kerja yang lainnya, diantaranya:

1. Hanya sebatas melamar kerja online

2. Posting lowongan kerja

3. Membuat resume

Setelah melakukan analisis terhadap situs lowongan kerja yang lainnya maka diberikan fasilitas yang membuat member lerbih berperan aktif dalam menggunakan aplikasi lowongan kerja.

Analisis Kebutuhan Fungsional

1. Diagram Konteks

Diagram konteks merupakan arus data yang berfungsi untuk menggambarkan hubungan input/output antara sistem dengan dunia luarnya (kesatuan luar). Adapun diagram konteks untuk sistem yang akan dibangun dapat dilihat pada gambar 1 berikut ini. 


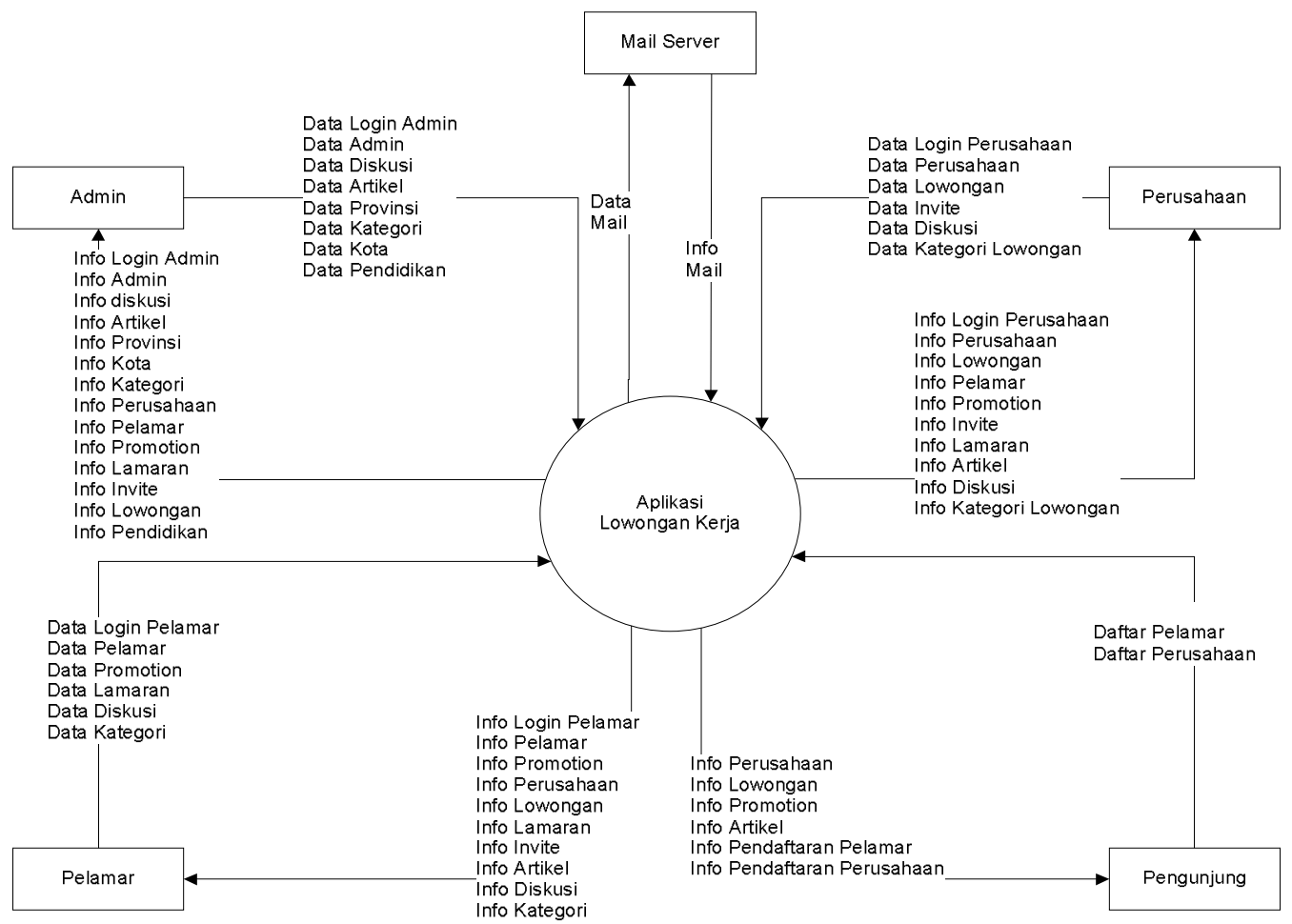

Gambar 1. Diagram Konteks aplikasi Lowongan Kerja Berbasis Web

\section{DFD Level 1}

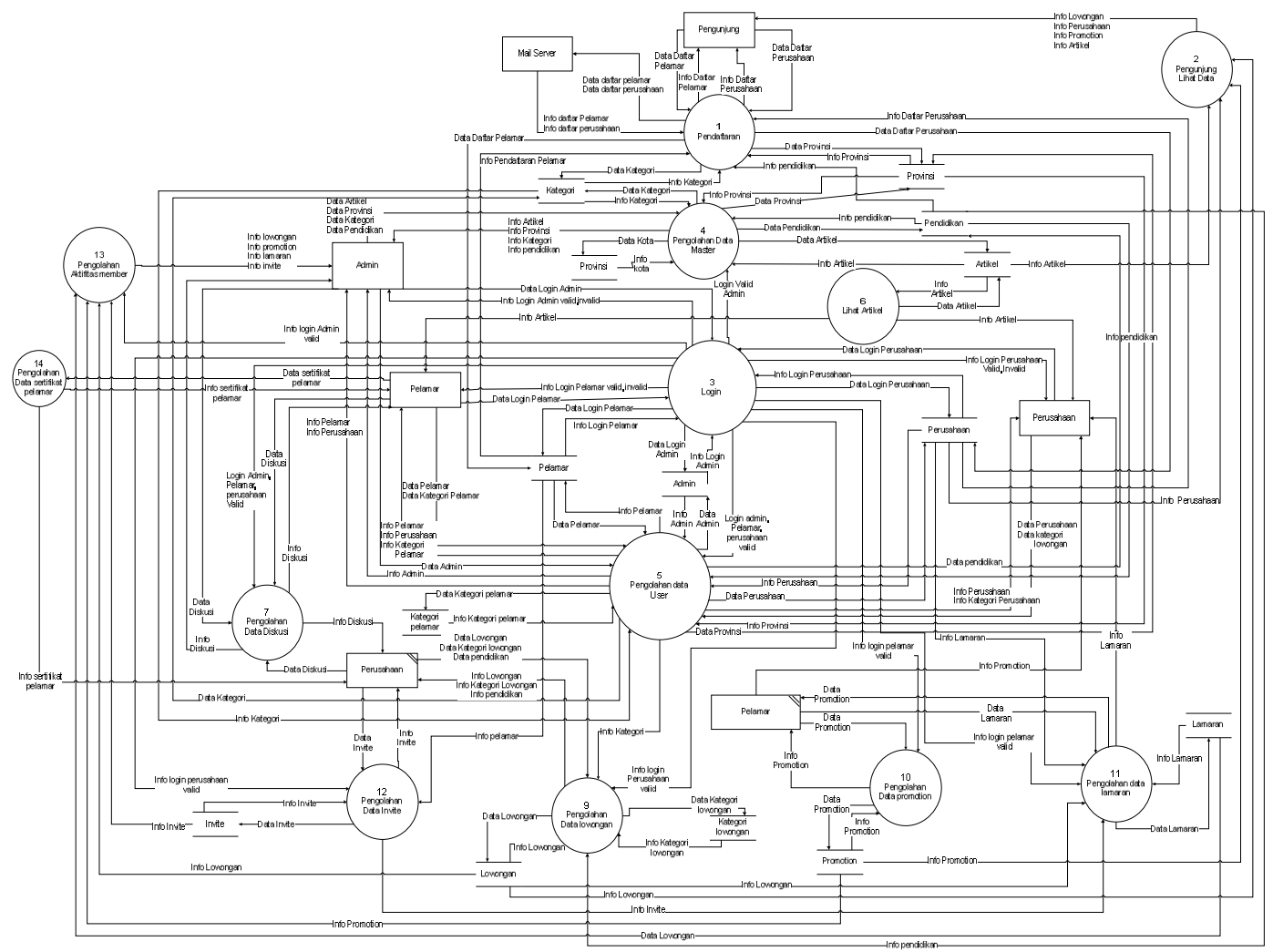

Gambar 2. DFD Level 1 aplikasi Lowongan Kerja Berbasis Web 


\section{Skema Relasi}

Skema relasi menggambarkan hubungan antar data, arti data dan batasannya dijelaskan dengan baris dan kolom, Adapun skema relasi yang terdapat pada aplikasi lowongan kerja berbasis web pada Gambar 3.

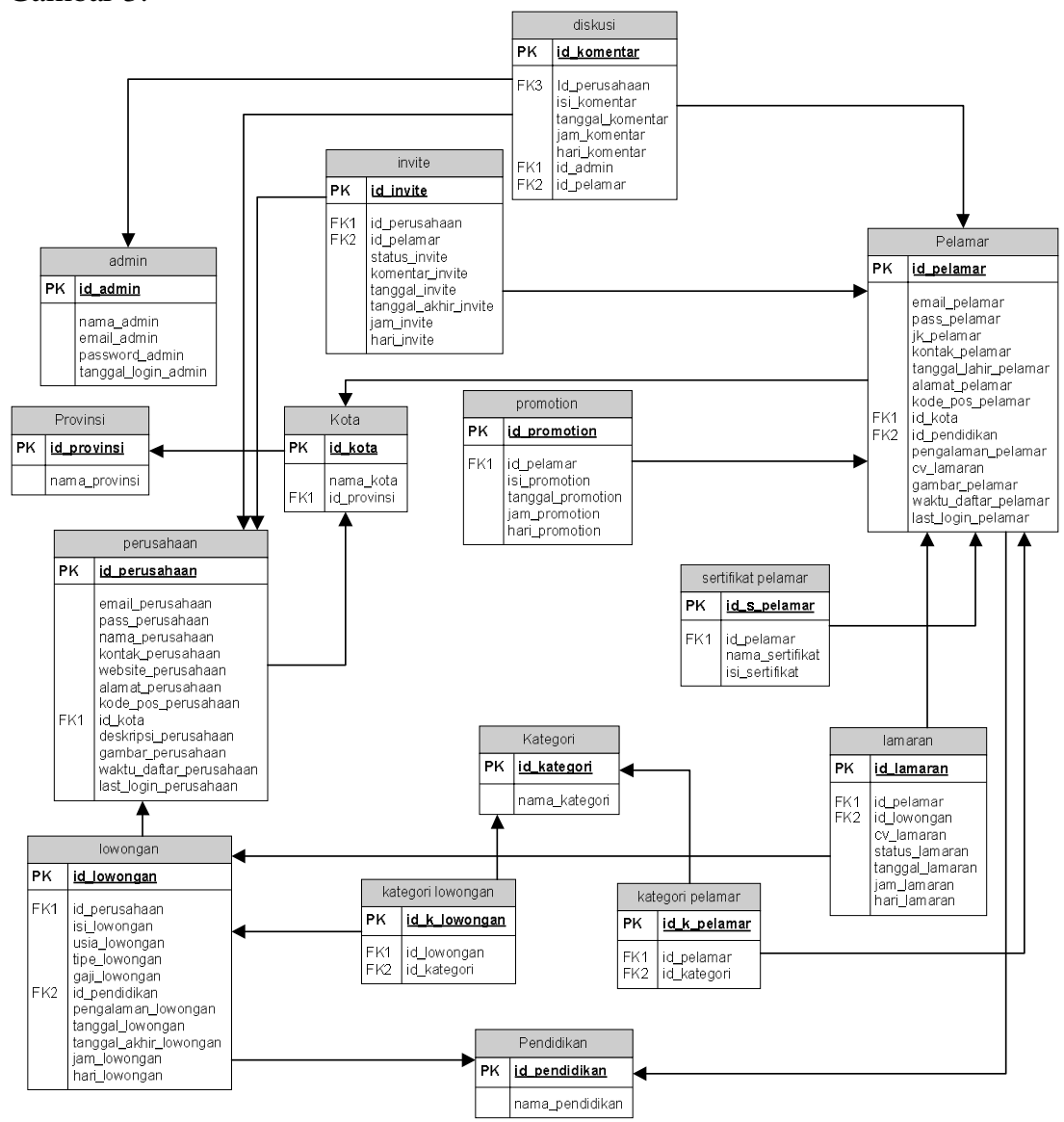

Gambar 3. Skema Relasi aplikasi Lowongan Kerja Berbasis Web

\section{Desain}

Desain struktur menu merupakan jalur pemakaian sistem yang mudah dipahami dan mudah digunakan. Perancangan struktur menu dari pembangunan aplikasi lowongan kerja berbasis webdibagi menjadi empat pengguna pada Gambar 4-7.

a. Struktur menu pengunjung

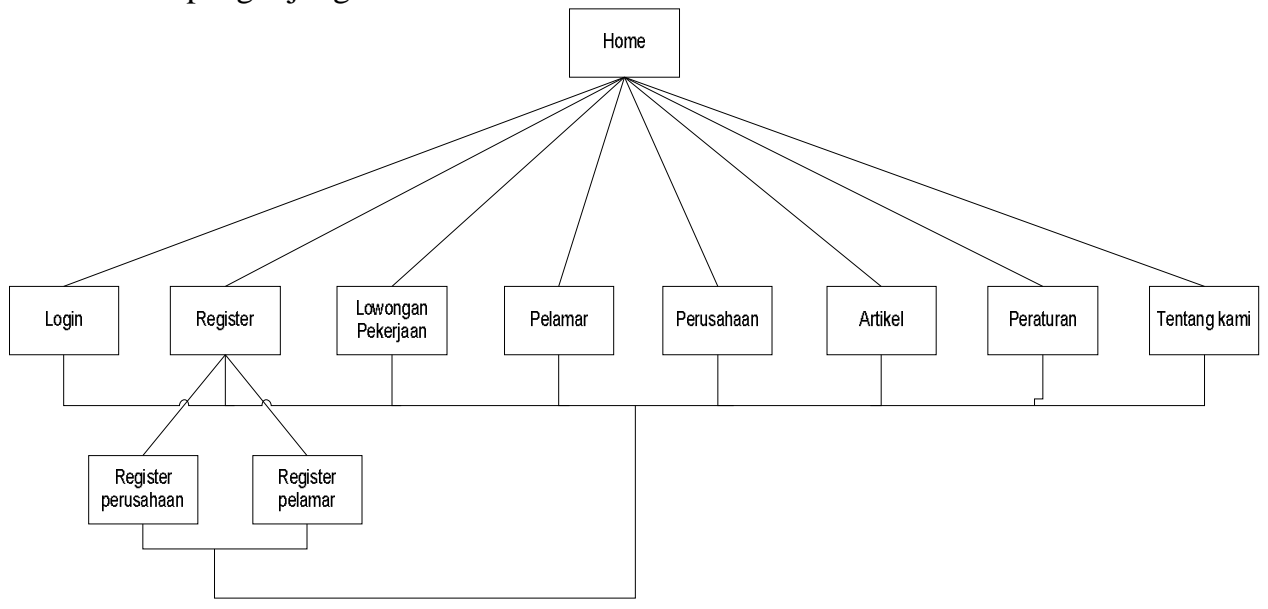

Gambar 4. Struktur Menu Pengunjung 
b. Struktur menu pelamar

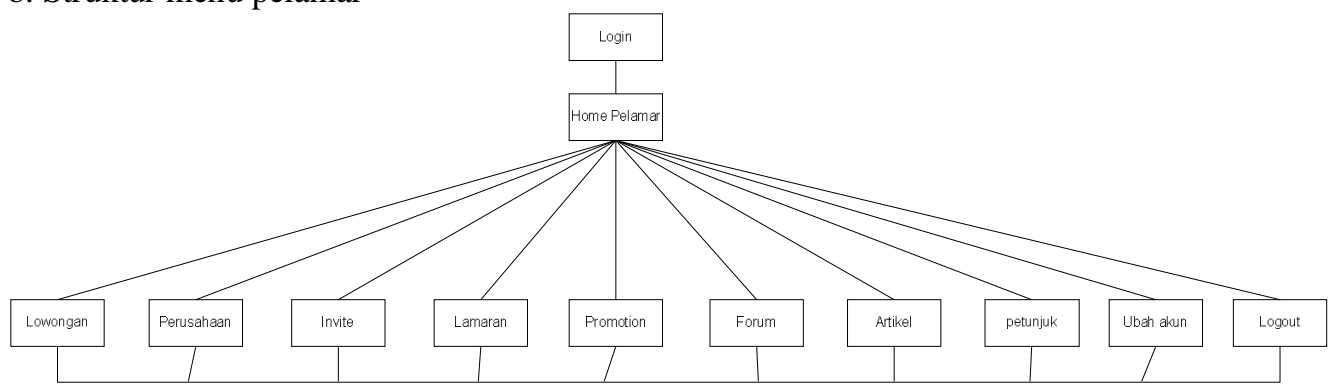

Gambar 5. Struktur Menu pelamar

c. Struktur menu perusahaan

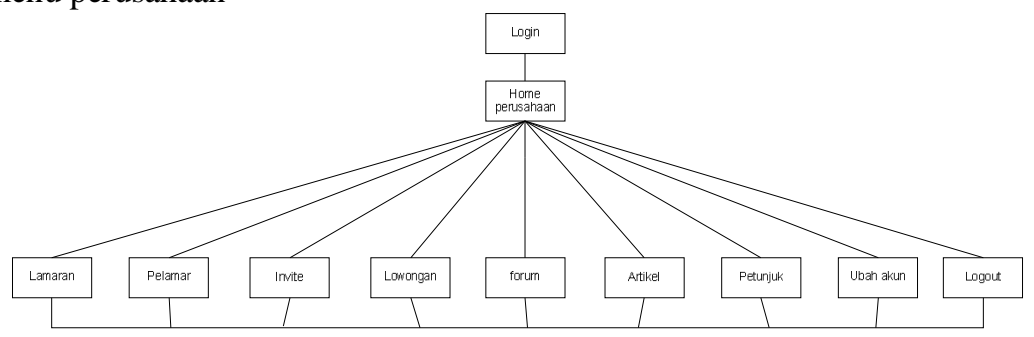

Gambar 6. Struktur Menu perusahaan

d. Struktur menu admin

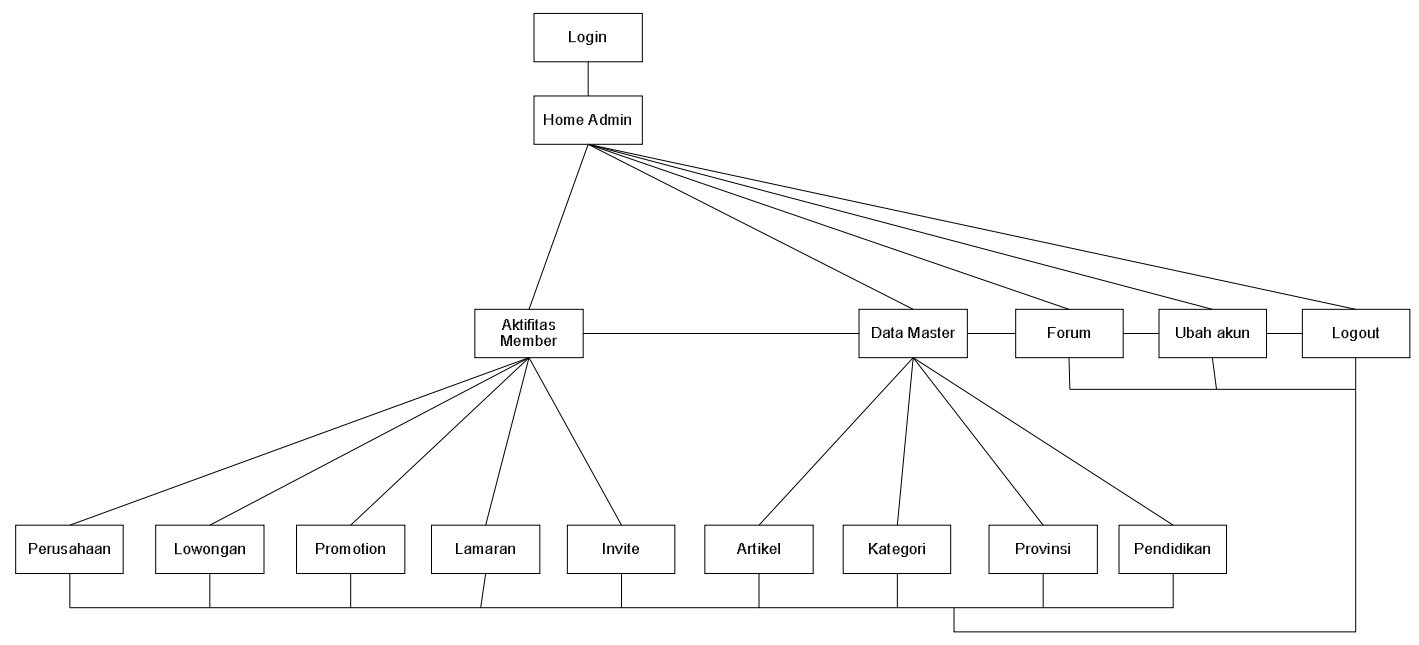

Gambar 7. Struktur Menu Admin

D. Implementasi

Tahap implementasi sistem merupakan tahap penciptaan perangkat lunak, tahap kelanjutan dari kegiatan perancangan sistem. Tahap ini merupakan menerjemahkan perancangan berdasarkan hasil analisis dalam bahasa yang dapat dimengerti oleh mesin serta penerapan perangkat lunak pada keadaan yang sesungguhnya.

Implementasi yang

dilakukan diantaranya implementasi perangkat lunak, implementasi perangkat keras, implementasi basis data, implementasi antarmuka.

Berikut salah satu implementasi antarmuka.

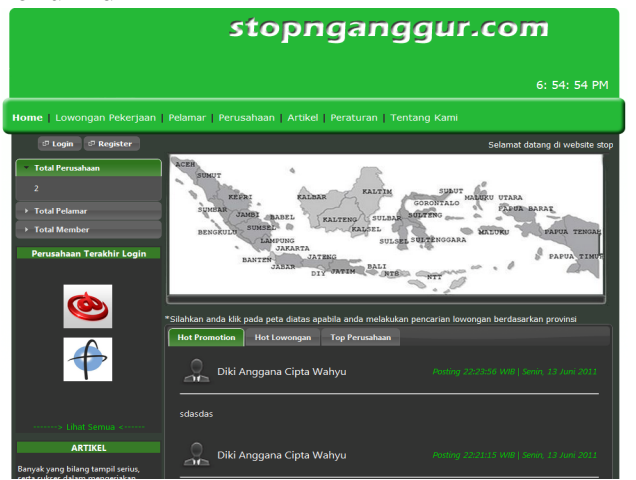

Gambar 8. Implementasi antarmuka pengunjung 
III.

\section{HASIL DAN DISKUSI}

Berdasarkan hasil pengujian sistem(alpha) yang telah dilakukan secara keseluruhan memberikan kesimpulan bahwa pada proses pada situs lowongan kerjatelah melalui tahap perbaikan dan sudah dimaksimalkan terhadap proses-proses tersebut dan secara fungsional sistem sudah dapat digunakan dan menghasilkan output yang diharapkan.

Berdasarkan hasil yang didapatkan dari pengujian betha pengguna pengunjung, pelamar dan perusahaan maka penerapan aplikasi lowongan kerjasesuai dengan tujuan yang ingin dicapai yaitu

1. Tampilan dari aplikasi lowongan kerja ini sudah baik .

2. Intruksi dari tiap fungsionalitas mudah dipahami.

3. Fasilitas artikel sangat membantu para member mengenai informasi-informasi tentang pekerjaan.

4. Fasilitas pencarian yang diberikan sudah baik dan memudahkan bagi para pelamar maupun perusahaan untuk mendapatkan sesuai dengan yang dicari.

5. Perusahaan dapat dengan mudah untuk mendapatkan pelamar yang sesuai dengan yang diharapkan.

6. Pelamar dapat dengan mudah mendapatkan lowongan yang sesuai dengan kategori yang dipilihnya.

7. Pelamar dapat dengan mudah untuk melamar kepada lowongan yang telah dikeluarkan oleh perusahaan.

8. Pelamar dapat berekspresi dan menuangkan pikirannya melalui fasilitas promotion.

9. Tiap member dapat saling berkomunikasi melalui fasilitas diskusi.

\section{IV.}

KESIMPULAN DAN SARAN

A. Kesimpulan

Berdasarkan perbandingan antara tujuan pembangunan perangkat lunak yang akan dibangun dengan hasil pengujian baik secara alpha maupun betha maka diambil kesimpulan sebagai berikut:

\section{B. Saran}

Terlepas dari kelebihan-kelebihan, sebuah perangkat lunak pastilah memiliki kekurangan-kekurangan yang sifatnya masih dapat dikembangkan lagi di kemudian hari. Adapun saran-saran dalam pengembangan aplikasi lowongan kerja berbasis web ini adalah sebagai berikut:

1. Aplikasi dapat disempurnakan dengan menyertakan fasilitas notifikasi bagi para pengguna terdaftar sehingga memudahkan para pengguna untuk mengetahui informasi terbaru mengenai akunnya dengan efektif.

2. Aplikasi dapat dikembangkan dengan menyediakan fasilitas chatting sehingga dapat mempermudah komunikasi antarpengguna.

3. Dengan menyediakan fasilitas pencarian yang lebih detail dan semakin mempermudah para pengguna.

4. Tampilah aplikasi semakin dibuat lebih menarik

V.

DAFTAR PUSTAKA

[1] Betha, Ir, Husni I. Pohan, Ir.M.Eng. (2009),Pemrograman Web dengan HTML Revisi Kedua. CV Informatika,Bandung.

[2] HM, Jogiyanto. (2005), Analisis dan Desain Sistem Informasi, Andi, Yogyakarta.

[3] Kadir, Abdul. (2008). Dasar pemrograman Web Dinamis menggunakan PHP,Andi, Yogyakarta.

[4] Madcoms. (2008), Panduan Lengkap Adobe Dreamweaver CS3, Andi Publisher, Madiun.

[5] Madcoms. (2008), Teknik Mudah Membangun Website dengan HTML, $P H P$ dan MySQL. Andi, Yogyakarta..

[6] Solichin, Achmad. (2010), MySQL 5:Dari Pemula Hingga Mahir, Achmatim.net, Jakarta.

[7] Sunyoto, Andi. (2007), AJAX Membangun web dengan teknologi Asynchronous JavaScript \& XML, Andi, Yogyakarta.

[8] Hakim, Lukmanul, Musalini Uus. (2006). Buku Sakti Menjadi Programmer Sejati. Solusi Media, Yogyakarta.

[9] Syafii, M. (2005), Aplikasi Database dengan PHP 5, Andi, Yogyakarta. 